\title{
ENTREVISTA - INTERVIEW
}

\section{Amado Luiz Cervo: Os anos de formação na Europa, 1964-1970}

\author{
Amado Luiz Cervo: The formative years in Europe, 1964-1970
}

\author{
Denis Rolland ${ }^{1}$ \\ Inspetor Geral, IGESR, ex-Reitor, \\ Universidade de Estrasburgo
}

Como citar este artigo: Denis Rolland. “Amado Luiz Cervo: Os anos de formação na Europa, 1964-1970", Intelligere, Revista de História Intelectual, nº10, pp. 26-45. 2020. Disponível em <http://revistas.usp.br/revistaintelligere>. Acesso $\mathrm{em} \mathrm{dd} / \mathrm{mm} /$ aaaa

Como posso prestar homenagem ao meu colega e amigo, professor Amado Luiz. Cervo, que, com a mediação de outros dois historiadores, Maria Eurídice de Barros Ribeiro, então sua nova colega em Brasilia, e Paulo Knauss de Mendonça, jovem professor no Rio, foi um dos meus apresentadores no Brasil e na história das relações internacionais brasileiras?

Talvez evocando um momento de sua formação, na França e dentro da instituição que ainda é minha, a Universidade de Estrasburgo: onde retomou seus estudos superiores e obteve um mestrado e depois um doutorado entre 1964 e 1970. Seis anos de vida não é pouco! Por isso, pensei em pedir-lhe algumas informações e tentar inclui-las em um artigo sobre o mundo universitário de Estrasburgo antes e depois de 1968 e sobre a recepção nesse mundo intelectual de um estudante sul-americano. Por conveniência, enviei a ele um questionário para orientar nossa conversa por telefone no dia seguinte. Como ele me disse, "bá

\footnotetext{
${ }^{1}$ Denis Rolland, professor titular da Universidade de Estrasburgo, especialista em Relações Internacionais e na América Latina (séc. 20). Criador e diretor do grupo FARE de pesquisa em Relações Internacionais (UMR7367 Dynamiques Européennes). Foi reitor das Academias da Guiana, de Dijon, de Caen e da Normandia (França). É atualmente Inspetor Geral da Educação Nacional. Publicou 10 livros autorais e organizou cerca de 50 livros coletivos em Relações Internacionais e História Contemporânea. Foi diretor científico adjunto no CNRS (INSHS) e membro junior e depois senior do Institut Universitaire de France.

Contato: denistolland@gmail.com
} 
muitas perguntas": ele finalmente respondeu ao questionário no dia seguinte - por escrito ${ }^{2}$. Todo mundo conbece o profissionalismo e o perfeccionismo de Amado.

Portanto, o mais útil parece publicá-lo, como está, com alguns comentários.

O interesse de seu testemunho vai muito além do desejo de entender melhor seu itinerário e de completar um pouco a biografia de um grande professor. Este é um itinerário em meados do século XX: ser brasileiro na França após o golpe de Estado contra João Goulart, um "refugiado" sem status além do de estudante, sem dinheiro; um estudante estrangeiro na França em uma grande universidade do interior antes e durante 1968. Seja um sul-americano descobrindo, além da França, este Velho Mundo da Guerra Fria, as duas Europas, de ambos os lados do Muro, e o Oriente Médio...

Quando ele fala sobre suas viagens pela Europa durante seus anos de formação e seu interesse formativo, é difícil não lembrar que, durante minha segunda ou terceira estada na Universidade de Brasilia, ele me disse um dia: "Denis: você não sabe nada sobre o Brasil, além do Rio e Brasilia, de suas universidades e arquivos. Pare! Tire uma semana em sua viagem de pesquisa aqui e vá explorar o país. Você voltará depois para continuar sua pesquisa! Por enquanto, vá para onde quiser, mas descubra e aprenda sobre o país!" Então eu parti. E, graças ao Amado, comecei a realmente aprender o Brasil.

Amado já contou para o CPDOC seu itinerário, incluindo suas memórias de formação na França - mas brevemente ${ }^{3}$. Aqui, ele desenvolve em grande parte este momento de sua vida, o que lhe dá, em um Velho Mundo centrado na Alsácia, títulos de formação universitária, talvez, também uma forma particular de rigor cientifico, mas também uma vida familiar e uma filha.

\section{A viagem}

\section{Por que sair do Brasil, no seu caso, em 1964?}

Em 1964 houve o golpe militar no Brasil, que duraria duas décadas. Eu saí do Brasil por duas razões: primeiramente, eu tinha medo do que poderia acontecer comigo; em segundo lugar, porque um amigo meu ganhou uma bolsa de estudo para a Universidade de Estrasburgo e eu decidi, simplesmente, que iria

\footnotetext{
2 23de Julho de 2020.

${ }^{3}$ Amado Luiz Cervo (depoimento, 2017). Rio de Janeiro, CPDOC/Fundação Getulio Vargas.
} 
com ele. Nós estávamos fazendo o curso superior de filosofia. Falei com meu irmão, que trabalhava em uma fábrica de móveis, e ele concordou em me pagar a passagem de navio. Desde aquela época, sempre pensei que a gente faz a vida como quer. Basta ter força de vontade e alguma sorte.

\section{Sair do país, só por pertencer a uma associação estudantil?}

Não. Eu pertencia ao centro acadêmico da faculdade, o que existia em qualquer faculdade no Brasil. Mas os centros acadêmicos eram investigados pelos militares, que queriam saber se eram conduzidos por esquerdistas radicais, como comunistas. Ter medo, era natural nessas condições.

\section{A associação era marxista ou só de esquerda?}

Pode-se dizer que o Centro Acadêmico era uma organização de esquerda, não marxista. Mas a esquerda era também visada pelos militares. Todo o movimento estudantil se voltou contra a ditadura militar, que os próprios militares chamavam de revolução, sem contudo cativar os estudantes. Estudante é idealista: acha que o mundo deve ser perfeito. Vivem um pouco no mundo da lua, como se diz, porque o mundo nunca foi e nunca será perfeito, a não ser na cabeça cheia de teorias dos estudantes. A perseguição aos líderes estudantis era real, e causava medo.

\section{Você tem uma lembrança da viagem?}

Guardo boas lembranças dessa viagem, que durou 16 dias, de Santos ao Havre. O navio era francês e se chamava Louis Lumière. O Atlântico Sul e o Atlântico Norte estavam calmos. Só na costa de Portugal houve mar agitado e o navio balançou muito. Estômago embrulhado. A melhor lembrança da viagem foi um pequeno grupo de franceses, homens e mulheres, que se interessaram por mim, como se eu fosse um jovem esperto, e gostavam de falar comigo. Aproveitei para treinar meu francês. Só sabia o que aprendera na escola de segundo grau e nunca havia praticado a língua falada. Foi muito útil a aprendizagem da língua falada que pratiquei no navio. Eu os procurava nas refeições e eles gostavam de falar francês, apesar do meu mau jeito de falar. Sabiam que estavam me ajudando. 


\section{Qual é sua primeira lembrança da chegada ao Havre e à França?}

O trem. Corria muito. Deixava ver a paisagem, que não era novidade, porque era parecida com paisagens do Brasil, onde eu andara muito de trem. Eram confortáveis.

\section{Passou por Paris e visitou Paris no trânsito?}

Passei por Paris, rapidamente, não visitei a cidade. Uma conexão de trem conduziu-me logo a meu destino, Estrasburgo.

\section{E depois? Lembranças?}

Quando o trem deixou Paris, minha ansiedade crescia. Que será a Universidade, que será a cidade, como será minha vida nova? Que significa ser estudante numa universidade francesa? Como vou sobreviver sem dinheiro? Tudo era novidade.

\section{Amado Luiz Cervo, num itinerário de formação tradicional: os Latino- Americanos e a França \\ No século XIX e no começo do século XX, os ricos "fazendeiros, gaúchos, portenhos hacendados, científicos..." latinoamericanos eram onipresentes em Paris e nas margens da França ... Essas elites econômicas e políticas da América Latina para quem o partido La Vie Parisienne era a fonte necessária de uma verdadeira cultura - julgada por outros como cosmopolita - um espaço de identidade essencial, um tempo essencial no calendário da vida social. É o período, como François-Xavier Guerra escreveu, da "luz e seu reflexo", quando as elites da América Latina desejavam voluntariamente ser o "espelho de Paris". Se alguns, contra a má sorte, escolheram Paris como uma terra de exílio enquanto esperavam por possíveis tempos melhores (como o imperador Dom Pedro $\mathrm{II}^{4}$ ou o mexicano Porfirio Díaz, ambos morreram em Paris), muitos latino-americanos vieram buscar na França, no coração do referencial do Velho Mundo, uma atmosfera e uma cultura consideradas matriciais. Para muitos desses latino-americanos, brasileiros, mexicanos, argentinos ..., a França é então frequentemente vista como um "ser ideal", identificado a partir do}

${ }^{4}$ Carvalho, José Murilo de, D. Pedro II: ser ou não ser, São Paulo, Companbia das Letras, 2007. 
século XIX com um "novo sistema de valores, e esse novo sistema de valores, é de Paris que brilha" 5 .

Essa presença predominantemente oligárquica, no entanto, deixou poucos vestígios na cultura francesa, além da imagem fútil, não muito gratificante, mas estereotipada, do rico brasileiro da opereta La Vie Parisienne d'Offenbach, levando um grande estilo de vida e dificilmente brilhando por sua própria cultura. Ao mesmo tempo e no mesmo período, muita literatura francesa é lida através do Atlântico, geralmente na versão original ou, posteriormente, traduzida, enquanto a iconografia "à francesa" está muito presente nas ruas dos centros monumentais das cidades latino-americanas; mas, até a segunda metade do século XX, a literatura latino-americana (e quase nada do idioma espanhol ou o português) atingiu apenas uma pequena fração do público francês ${ }^{6}$.

$\mathrm{Na}$ segunda metade do século $\mathrm{XX}$, as coisas mudaram gradualmente e a modificação do tipo de presença latino-americana na França fez parte desse desenvolvimento.

Após um lento declínio durante a primeira metade do século XX da presença tradicional latino-americana na França, chega a época dos exilados, oponentes aos regimes autoritários das décadas de 1960, 1970 e do início de 1980. Amado, sem ser ativista político, faz parte dos latino-americanos que escolhem o Velho Mundo como proteção - e oportunidade de formação. A maioria das jovens elites francesas, imbuídas dos valores de uma intelectualidade de esquerda muito dominante, se unem sob a bandeira romântica do Che guerrilheiro, este argentino cubanizado pelo gesto revolucionário ${ }^{7}$, ou, mais

5. François-Xavier Guerra, «La lumière et ses reflets : Paris et la politique latino-américaine » in A. Kaspi et A. Marès (dir.), Le Paris des étrangers, Paris, Imprimerie nationale, 1989, pp.171-183.

6. Ver Miguel Rodriguez et Nestor Ponce, «Un livre d'histoire aux gravures de pierre: monuments latino-américains à Paris", Actes du colloque L'Amérique latine et l'Europe, ALMOREAL, Université d'Orléans, 1995.

7. Ver em francês Pierre Kalfon, Che, Ernesto Guevara, une légende du siècle, Paris, Seuil, 2007; Miguel Benasayag, Che Guevara: du mythe à l'homme : aller-retour, Paris, Bayard, 2003 ; Olivier Besancenot e Michael Löwy, Che Guevara une braise qui brûle encore, Paris, Mille et une nuits, 2007 ; Jeannine Verdès-Leroux, La Lune et le Caudillo, Gallimard, Paris, 1989 ; Daniel James, Che Guevara, New York,Cooper Square Press, 2001; cf. também a parte « Le culte du Che » da 
tarde, no ano do retorno de Amado para o Brasil, por Salvador Allende e o Chile da Unidade Popular: esses dois líderes, heroizados, trazem para a juventude europeia duas modalidades de possível acesso ao poder, e o segundo a ideia de um "socialismo do possível".

\section{Estrasburgo: chegada, instalação e estudos}

\section{Quando chegou?}

Cheguei a Estrasburgo, não lembro mais do dia, nem do mês. Em 1964. Foi no início do ano letivo francês, após as férias de verão [Setembro?].

\section{A primeira lembrança de Estrasburgo?}

Fui alojado em um foyer estudantil dirigido por religiosos. Como meu amigo que recebera a bolsa. Era uma casa de estudantes, perto de l'Orangerie. Anos depois passei por lá como turista e o prédio havia sido demolido. Em seu lugar havia casas residenciais.

O bairro era de gente rica [e ainda é!]. É o bairro perto das instituições europeias, porque as casas eram luxuosas, espaçosas, lindas. A cidade era bem diferente das brasileiras. Era uma cidade histórica, de prédios e casas antigas. No Brasil era tudo diferente: prédios novos, sem muito charme, menos em cidades mais antigas, como Rio de Janeiro, Salvador. Era o velho mundo. E eu deixara o novo mundo. O contraste era perceptível. A cidade era maravilhosa, com suas igrejas, seus palácios, uma estrada na beira do rio que cortava a cidade, estrada que servia para os carros e para passear. A catedral impressionava, com sua torre de 163 metros de altura, uma torre só. Tudo era bonito. Eu era feliz.

\section{Foi acolhido bem ou não foi?}

Tudo era novidade. Decidi me adaptar ao velho mundo. Sempre de acordo, sempre satisfeito, nada de querer mandar nas pessoas e nas instituições. Fui acolhido muito bem pelo serviço de acolhida aos estudantes estrangeiros da própria Universidade. Havia um senhor que o dirigia, que era muito simpático

página wikipedia dedicada a Che Guevara (http://fr.wikipedia.org/wiki/Che_Guevara 072010). 
e dava risadas. Deixou-me muito à vontade, como se eu estivesse em meu país. $\mathrm{Na}$ Universidade, onde havia muitos estudantes estrangeiros, de diversos países, o pessoal de secretaria era gentil. Os professores eram um pouco distantes, não davam muita bola aos estudantes, davam boas aulas e iam embora.

\section{Houve dificuldades?}

A principal dificuldade era a falta de dinheiro. Meu irmão me dera um pouco de dinheiro, pouco, e o foyer era de graça, como também a Universidade. Mas nada de bares, restaurantes. Só passeios pelos cais, ver palácios, igrejas, a biblioteca, Biblioteca Nacional e Universitária de Estrasburgo: só havia em Paris e Estrasburgo com esse status de biblioteca nacional. Parece que a França queria prestigiar muito a Universidade de Estrasburgo, para arraigar a cultura francesa na cidade, sempre disputada com a Alemanha, durante as guerras. Conquistar o povo, aliás, de origem germana, pelo lado da cultura. Bom propósito, ao que parece aceito pelo povo local, de etnia germana, mas de coração francês. Essa era minha impressão de chegada.

A dificuldade era comprar livro. Eu queria, mas não tinha dinheiro. Certa vez, um professor, percebendo essa minha dificuldade, levou-me a uma livraria, perguntou que livros eu queria. Mostrei alguns, ele comprou todos, pagou e me deu de presente. Fiquei maravilhado.

\section{Que o surpreendeu mais?}

Nada me surpreendeu. Aceitei tudo como era, porque tudo era bom, eficiente, bonito. Eu era feliz, e sabia disso.

\section{Diferente do Brasil?}

Era tudo diferente. Mas adaptar-se é próprio do ser humano, como também é prova de inteligência prática. Então, adaptei-me à nova vida, à língua, à comida. E sem dinheiro.

\section{Uma lembrança da primeira aula na Universidade?}

Não guardei. Conservo lembrança das aulas. Os estudantes tomavam nota de tudo o que o professor dizia, depois estudavam nessas notas com outros 
colegas da mesma classe para preparar as provas. Elas eram exigentes e requeriam muito estudo, tanto nas notas de aula, quanto na biblioteca, lendo livros sobre os temas da aula. Era uma vida de estudante bem séria.

\section{O que achou do estilo de ensinar na Universidade?}

Os professores davam suas aulas, os estudantes só podiam fazer perguntas quando ele permitia. Alguns permitiam facilmente, outros não. O professor era o dono da classe. Duas coisas se conjugavam: anotar e complementar o estudo com leituras na biblioteca. Conversas durante a aula provocavam o berro do professor. Todos ficavam em silêncio, anotando os ensinamentos.

\section{Que professor o impressionou mais?}

Nenhum. Eles tinham estilos próprios, uns mais alegres, outros mais carrancudos. Mas todos eram bons professores. Eu passei a me interessar mais pelas disciplinas que se baseavam na História. Percebi que teorias enchem a cabeça de confusão, mais que de conhecimento. Seria a História a substância do bom conhecimento? Parecia-me que sim. E eu aprendi isso com meus professores. Conhecimento objetivo, seguro, científico, somente com fundamento histórico. Isso na área das ciências humanas, não me refiro às exatas e outras, que não conheço.

Os professores que praticavam essa metodologia eram os que me impressionavam mais, e eram todos os que eu ouvia na Universidade.

\section{Como foram suas relações com o orientador da tese?}

Chamava-se François Châtillon, o meu orientador de doutorado ${ }^{8}$. O de mestrado, não lembro. Ao chegar, tive de pedir revalidação de disciplinas que cursara na faculdade no Brasil. Não foi fácil. Mas meu orientador era gentil. Além de ensinar, convidava-me para ir ao restaurante, por vezes até passear em cidadezinhas do Alto Reno. Um luxo.

\footnotetext{
8 "Eu saí da filosofia, tinha até começado uma faculdade lá de teologia, que fornecia bolsas e tal, mas... (eu terminei, inclusive, esse curso), mas eu fiz história; depois, eu fiz o mestrado em história e o doutorado em história, então a minha formação é realmente de história. A minha tese de doutorado foi sobre a conquista espanhola da América, que eu publiquei, Contato entre Civilizações: conquista [e colonização] espanhola[s] da América" (Cervo, Amado Luiz, depoimento, 2017, Rio de Janeiro, CPDOC/Fundação Getulio Vargas).
} 
Lembro de minha defesa. Um professor perguntou-me como escrevera minha tese em um francês tão intelectual e elegante. Ficou sem resposta. Tempos depois ocorreu-me o porquê. Eu só mantinha contato com aula, livros, biblioteca, ou seja a língua científica, não a língua falada, com seus vícios. Por isso meu texto ficou elegante, de bom francês. A tese tratava sobre a conquista da América pelos espanhóis [Service de Dieu et Service de Sa Majesté : La justification espagnole de la conquête de l'Amérique 1492-1548]. A biblioteca dispunha de uma grande quantidade de livros escritos desde o século XVI, em espanhol. Foi a matéria prima de minha tese, que versava sobre o choque de civilizações. Meu orientador parecia meio perdido, porque não conhecia esse material. Confiava em mim e me deu apoio na hora da defesa?.

\section{Voce teve dificuldades administrativas?}

$\mathrm{Na}$ Universidade de Estrasburgo não havia dificuldades administrativas. Estudar era tarefa desenvolta, ao alcance dos alunos.

As dificuldades administrativas foram as de reconhecimento dos diplomas, terminado o curso. Era preciso revalidar a assinatura do diretor, tanto por cartórios franceses como por autoridades do consulado brasileiro em Paris. Chegando ao Brasil, era preciso reconhecer as assinaturas das autoridades consulares. Uma burocracia da pesada. Além da revalidação dos diplomas. Muita burocracia. Coisa que sempre detestei.

Qual foi a sua impressão a respeito da maneira de apresentar na França o Brasil e a América Latina?

O conhecimento popular sobre Brasil e América Latina, nos anos 1960, na França, era precário. Ficaram os estereótipos de escritores franceses, como Montaigne. Nós seríamos meio naturais, selvagens, diferentes de civilizados. Por certo, os professores não pensavam assim, aliás, não pensavam nada. Não ensinavam mais do que liam em livros, franceses. $\mathrm{O}$ conhecimento erudito também era precário. Essa era minha impressão.

\footnotetext{
${ }^{9}$ Amado Luiz Cervo, Service de Dieu et Service de Sa Majesté : La justification espagnole de la conquête de l'Amérique 1492-1548, Travaux universitaires papier - 1970, Bibliothèque des Facultés de théologie catholique et protestante, université de Strasbourg. Sob a direção do P. François Châtillon (1908-1994), historiador da Idade Média, professor na Faculdade de Teologia Católica de Estrasburgo, fundador e diretor da Revue du Moyen Age latin, publicado pelo CNRS (CNPq francês).
} 
Durante a ditadura militar no Brasil, o país era ligado à tortura. A conexão cognitiva era simples: Brasil-tortura. A imprensa francesa parecia-me muito ignorante.

Quando cheguei de volta ao Brasil, em 1970, cheguei tremendo. Acreditava que ia passar por uma boa sessão de tortura, em razão da imagem que a imprensa francesa exibia do país. Nada disso aconteceu.

Um episódio, logo depois da chegada, revela isso. Apresentei-me ao quartel, em minha cidade, porque estudante brasileiro no exterior tinha o serviço militar adiado até o retorno. Eu precisava regularizar minha situação militar. Apresentei-me ao quartel e fui entrevistado por um coronel. Ele me deixou logo à vontade. Respondi a todas as suas perguntas. Quando falei da conexão Brasil-tortura que a imprensa francesa fazia, e de meu medo ao chegar, ele dava gargalhadas. E dizia: Paris é a capital do anti-Brasil. Brincou comigo: vou mandar você fazer o serviço militar, é só um ano. Na realidade era brincadeira. Passou-me o documento oficial de regularização de minha situação militar, que me serviu para sempre.

\section{Você manteve contatos com o Brasil?}

Eu tinha amigos brasileiros, estudantes. A gente conversava muito. Além disso, eu lia a imprensa francesa sobre o Brasil, diariamente.

\section{$E$ você recebia cartas do Brasil?}

$\mathrm{Eu}$ recebia cartas de meus familiares, frequentemente. $\mathrm{Na}$ época era o único meio de comunicação. Eu me sentia bem informado. E nem estava preocupado com isso, estudos e pesquisas me absorviam e ocupavam minhas preocupações e meu tempo.

\section{O que achava da censura?}

Fiquei sabendo da censura no Brasil, durante o regime militar, anos depois de voltar. Na primeira universidade onde trabalhei, nada de censura. Quando me transferi para a Universidade de Brasília, fui convidado para ser professor do Instituto Rio Branco, a escola brasileira de formação de diplomatas. Fiquei então sabendo da censura praticada pelos militares. Minhas cartas enviadas aos familiares no Brasil eram todas abertas pela censura. Inclusive aquela em que 
descrevia minha viagem à União Soviética, quando estudante em Estrasburgo. O diretor do Rio Branco leu-me que, segundo a consulta que fizera ao serviço de inteligência do regime militar, eu fiquei bem impressionado com o regime comunista, e falava dos benefícios dele para o povo, em termos de igualdade e justiça social. Assim mesmo, fui contratado e tornei-me professor da escola brasileira de diplomacia.

Na França, você tinha contatos com brasileiros, latino-americanos, associações políticas brasileiras e francesas, partidos políticos?

Em Estrasburgo eu mantinha muito contato com brasileiros e latinoamericanos. Eles aliviavam minha saudade. Nós nos encontrávamos no restaurante universitário, nos bares, em viagens. Falar português era como sentir-me em casa. Quando estudante, nunca fui membro de associações políticas francesas ou brasileiras, tampouco de partidos políticos. Isso tudo não me interessava. Os estudos absorviam o meu tempo.

\section{3. "Maio de 68" na França, viagens e volta ao Brasil}

\section{Qual era o ambiente universitário antes de 1968?}

Era calmo, entre os estudantes, até 68. Nasceu então um movimento estudantil de esquerda, pendendo para o lado revolucionário.

\section{E 68 em Estrasburgo?}

As agitações nas universidades se esparramaram sobre a França e outros países europeus. Em Estrasburgo, havia um movimento bem radical de estudantes: eram os situacionistas. Até hoje não entendo por que se chamavam assim. Eu não me filiei a nenhum movimento organizado, mas era envolvido, como todos.

\section{Lembra-se da ocupação do Palais Universitaire?}

O Palais era a sede da Universidade, o palácio mais imponente e nobre da Universidade. Nele eram oferecidos alguns cursos. Os estudantes tomaram conta, fizeram uma barreira na entrada.

\section{Que lhe pareceu 68 na França?}

Uma festa. Era divertido. 
Quando as aulas foram interrompidas, eu fui a Paris. A festa continuava. Os estudantes erguiam barricadas nas ruas da cidade, imitando as barricadas da época da Revolução Francesa: deste lado os revolucionários, do outro o inimigo. Apanhavam, se dispersavam em um lugar, se aglomeravam logo adiante, em outro. A mim parecia uma festa.

O movimento começou com os estudantes, mas logo os sindicatos de operários aderiram e uma greve geral, nacional, paralisou o país. Quer dizer: os estudantes triunfavam.

Se bem me lembro, o Presidente Charles de Gaulle cansou, não conseguia controlar a situação, que julgava poder enfrentar com a força. Demitiu-se no ano seguinte.

\section{Os gaullistas?}

Apareceu então o Primeiro ministro Georges Pompidou: mais cauteloso, inclinou-se para o lado da negociação. Os sindicatos logo apresentaram propostas e os salários dos operários melhoraram. Os estudantes não sabiam bem o que queriam, mas não viam mais os operários a seu lado, nas agitações sociais. Com o tempo, o movimento estudantil foi esfriando e a vida, depois de meses, voltou ao normal para todos.

\section{Que foi então seu balanço do movimento?}

Eu era estudante, não filiado a nada, a não ser a meus estudos. Mas envolviame no movimento social, que, para mim, estrangeiro cauteloso, era um movimento para ver, não para comandar. Creio que o movimento alcançou resultados concretos, tanto para os estudantes, que encurtaram a distância que os separava dos professores, quanto para os trabalhadores, que tiveram aumento de renda, quanto para os empresários, que passariam a vender mais e a fortalecer suas empresas.

Um ganho coletivo, uma segunda revolução francesa. 


\section{E um balanço hoje?}

Vendo de longe, maio de 68 creio ter sido um movimento que, de certa maneira, trouxe resultados positivos, para toda a Europa e para outros países, especialmente os americanos. Os ganhos sociais, trabalhistas, a melhoria da igualdade social, a influência sobre a vida política, o maior cuidado com os interesses do povo, de seu bem estar.

Até que a corrupção dos dirigentes políticos, em países da América Latina, requeira outro movimento com senso de moral política, maio de 68 permanecerá uma advertência. A menos que seja esquecida por todos.

"Maio de 68": na Alsácia de Amado, uma universidade pioneira dos eventos, mas não revolucionária

$\mathrm{Na}$ década de 1960, para acomodar o crescente corpo estudantil dos Trinta Gloriosos, a Universidade de Estrasburgo se expandiu: novas instalações foram construídas no coração do distrito da Esplanada ${ }^{10}$, extensão dos edifícios construídos pelo Reich alemão após a guerra de 1870, incluindo o neoclássico e imponente Palais Universitaire. Assim, a Faculdade de Direito mudou-se em 1962 para a Esplanada. Aqui estão os lugares onde Amado chegou em 1964. O contexto é o dos anos 1960, jovem e efervescente mas numa atmosfera acadêmica ainda muito tradicional e magistral.

Dois anos antes dos "eventos", a capital da Alsácia é um dos lugares privilegiados para a disseminação das ideias situacionistas e de suas críticas radicais. "Não é através da jovem Universidade de Nanterre que o movimento

\footnotetext{
${ }^{10}$ https://droit.unistra.fr/faculte/historique-de-la-faculte. Veja também Jean-Claude Richez e Léon Strauss, «Le Mouvement social de mai 1968 en Alsace : décalages et développements inégaux », in Revue des sciences sociales de la France de l'Est, no 17, 1989-1990, p. 117-121 e «L'Alsace, une région décalée », in René Mouriaux (dir.), 1968, exploration du mai français, t. 1, Terrains, Paris, L'Harmattan, 2000, p. 163-183.
} 
de Guy Debord toca os estudantes, mas através da de Estrasburgo"11. Prelúdio aos eventos de maio de 68, em 1966, um grupo de estudantes de Estrasburgo à frente da Associação Federativa Geral de Estudantes de Estrasburgo (AFGES) 12 "fizeram contato com a Internacional Situacionista", que defende o marxismo e os conselhos, uma "forma de socialismo libertário, antiestado e antileninista", com a perspectiva duma "revolução da vida cotidiana" que combina autogestão e abolição do "trabalho alienado"13. E na efervescência mundial da década de 1960, estoura “o escândalo de Estrasburgo" ${ }^{14}$ : esses estudantes vão imprimir e distribuir 10.000 cópias de uma brochura, Miséria no meio universitario, aspectos econômicos, politicos, psicológicos, sexuais e, em particular, intelectuais e alguns meios para remediá-la. Logo, 300.000 cópias em 6 idiomas foram impressas e distribuídas por toda a França, criticando os defensores das críticas sociais da época, listadas numa desordem voluntária: "Althusser - Garaudy Sartre - Barthes - Picard - Lefebvre - Levi Strauss - Halliday - Chatelet Antoine. Humanismo - Existencialismo - Estruturalismo - Cientismo - Nova crítica - Dialecto-naturalismo - Cibernetismo - Planetismo - Metafilosofismo". O panfleto acusa o estudante de "consumir" os livros dessa intelligentsia de esquerda que o fazem acreditar que é revolucionário, quando na verdade "a questão é sempre preservar sua posição cultural”"15.

Em 1968, o movimento de greve estudantil de Estrasburgo começou em 6 de maio. No dia 8, um grande evento reuniu estudantes e funcionários na capital da Alsácia. Em 11 de maio, cerca de 6.000 estudantes e 150 professores

\footnotetext{
${ }^{11}$ https://lemediapresse.fr/politique/le-scandale-de-strasbourg-lorigine-trop-meconnue-demai-68/

12 O site Internet da AFGES, que fornece alguns antecedentes históricos (fundada em 1923, criação de uma restauração universitária em La Gallia em 1927...), não menciona nada disso hoje (https://www.afges.org/qui-sommes-nous/28-07-2020). A AFGES era então filial local da grande união estudantil UNEF.

${ }^{13}$ https://lemediapresse.fr/politique/le-scandale-de-strasbourg-lorigine-trop-meconnue-demai-68/

14 André Bertrand, André Schneider [protagonistas dos eventos], Le scandale de Strasbourg mis à nu par ses célibataires, même, Montreuil, L'Insomniaque, 2018.

15 https://lemediapresse.fr/politique/le-scandale-de-strasbourg-lorigine-trop-meconnue-demai-68/
} 
proclamaram a "autonomia" da Universidade de Estrasburgo no Palácio Universitário ocupado, acima do qual a bandeira negra tremulou por um momento $^{16}$. O historiador tem muito poucos arquivos audiovisuais, porque existia apenas um canal de televisão na França; a censura proíbe transmitir imagens do evento universitário e, quando finalmente é autorizado, o pessoal do canal de televisão entra em greve!

$\mathrm{Na}$ Alsácia, os eventos de maio foram orientados por três movimentos estudantis: os situacionistas da AFGES, as Juventudes Comunistas Revolucionárias (JCR, trotskistas) e a $\mathrm{UNEF}^{17}$. Por meio dessa declaração de autonomia, os estudantes manifestam sua "recusa de um governo absolutamente incompetente em questões de educação nacional" e exigem "o reconhecimento do poder dos conselhos estudantis"; os mais moderados falam de "descentralização" ou mesmo de "cogestão" na vida universitária. Essa autonomia solicitada a partir de Estrasburgo torna-se rapidamente uma demanda nacional. Assim, quando três dias depois, o Ministro da Educação Nacional Alain Peyrefitte aceita que a Universidade de Estrasburgo experimente essa autonomia e faça propostas, apesar da intervenção nessa direção do reitor da academia, é tarde demais: outras universidades seguiram o exemplo e a resposta local moderada não é mais funcional. Naqueles dias, as universidades parisienses lideravam o protesto. Em Estrasburgo, como em outras partes da França, os estudantes expressam sua rejeição ao poder gaullista, denunciam a repressão policial e o controle da informação, pedem uma luta comum com os trabalhadores e exigem maior liberdade sexual ${ }^{18}$.

No $1^{\circ}$ de junho, uma contrademonstração gaullista em Estrasburgo, dois dias após a grande em Paris nos Champs Elysées, tenta retirar os estudantes do Palácio Universitário.

\footnotetext{
16 « Mai-68 à Strasbourg : pionnière mais pas révolutionnaire », 6-05-2018, Blandine Costentin, Patrick Genthon, France Bleu Alsace, Strasbourg https://www.francebleu.fr/infos/societe/photos-mai-68-a-strasbourg-les-slogans-les-affichesde-la-revolution-1524125793.

17 Exposition «Mai 68 en Alsace», BNU, 2018. Voir et aussi http://concoursalumni.unis*tra.fr/index.php?id=25479
} affiches-de-la-revolution-1524125793. 


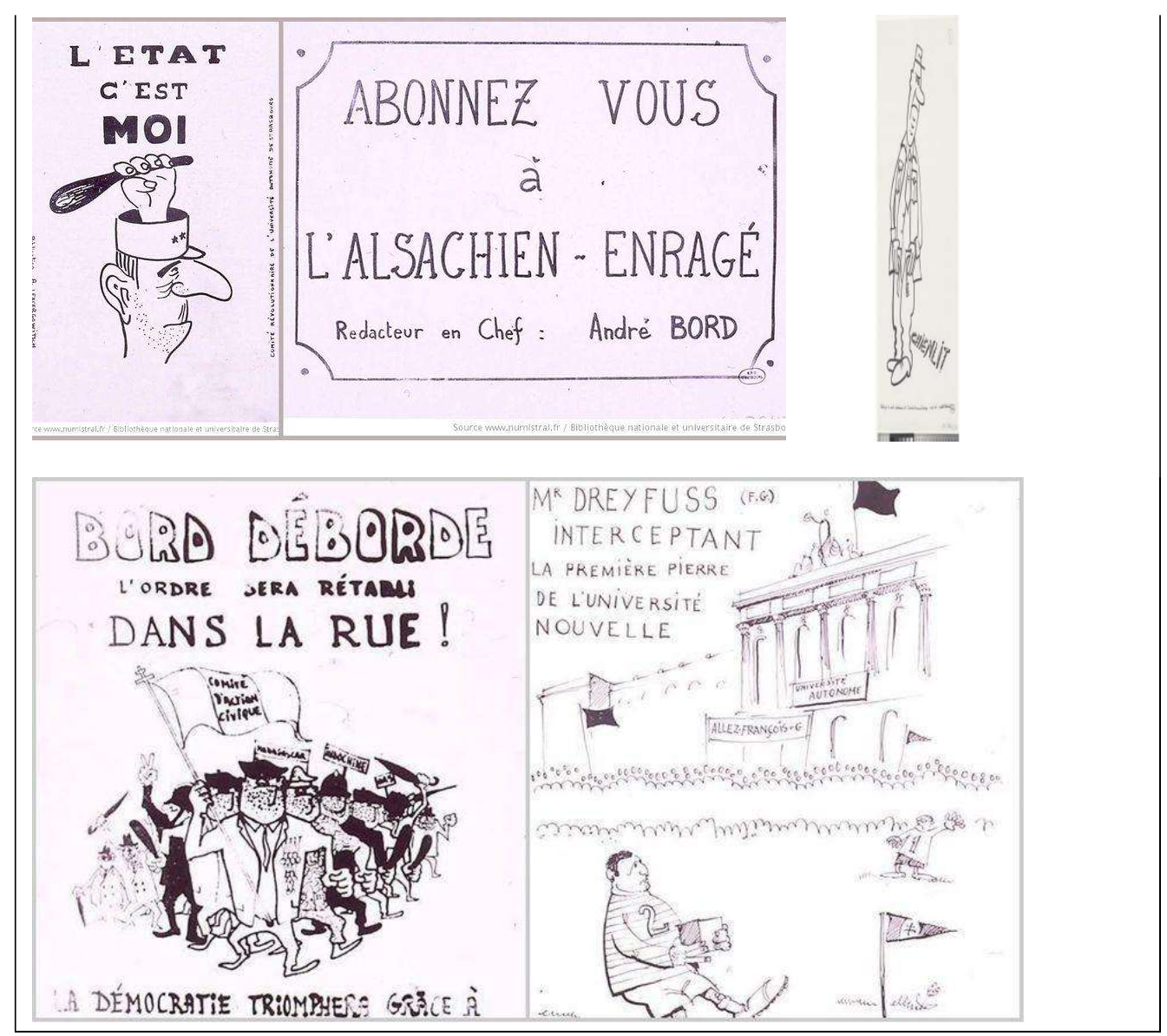

Folhetos de estudantes em Estrasburgo. Reações aos discursos do General de Gaulle, à repressão e ao apoio gaullista que tentaram invadir o Palácio da Universidade em $1^{\circ}$ de junho de 1968. Exposição " Maio de 68 na Alsácia", BNU, 2018.

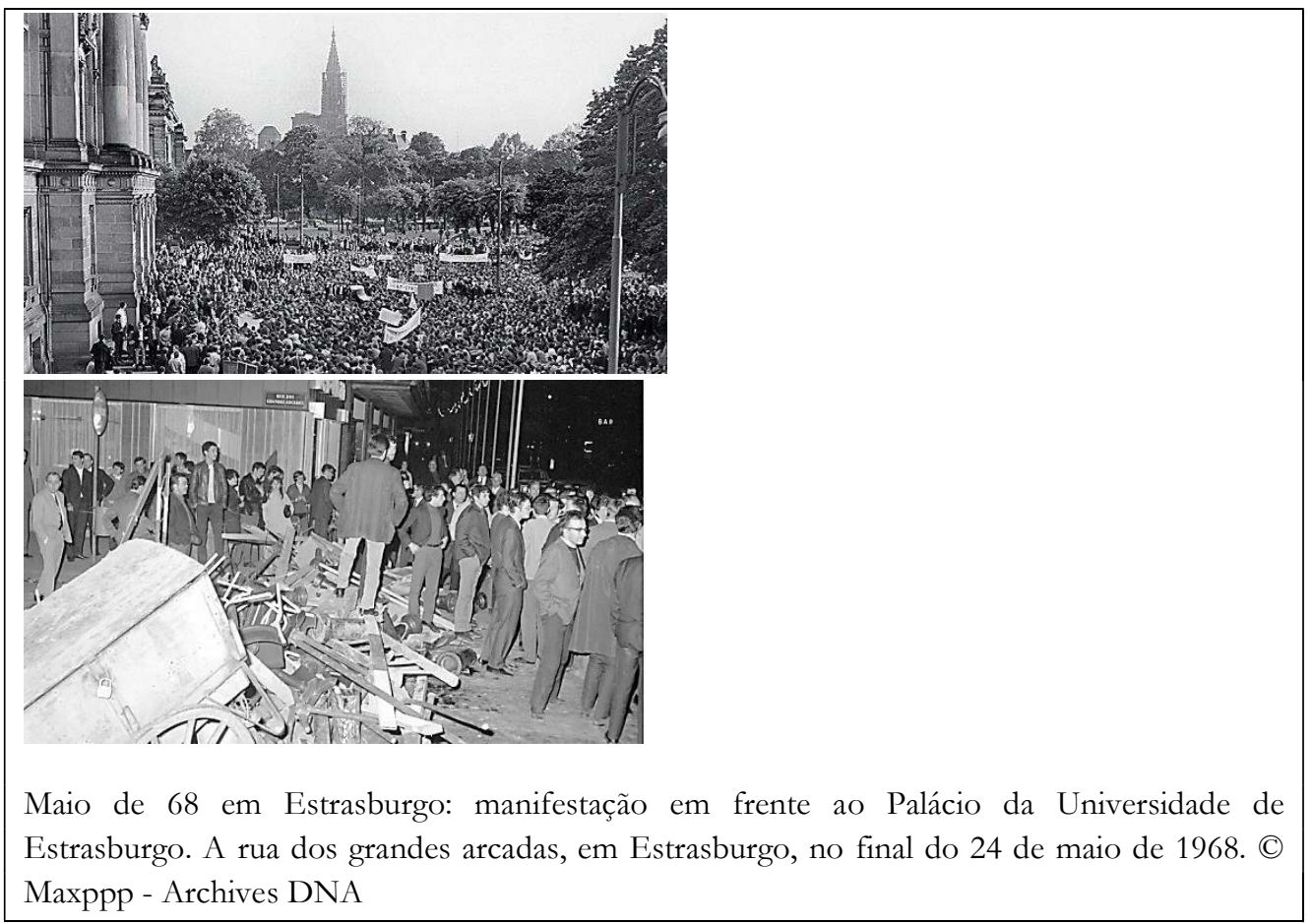




\section{Você fez viagens na Europa, antes de ir a Moscou?}

Quando cheguei a Estrasburgo, eu era bem pobre, quase sem dinheiro. Só me restava estudar, estudar muito. A recompensa veio ao termo do primeiro ano de estudo.

Eu pedi bolsa de estudo para todo lado. Como minhas notas eram boas, recebi três bolsas ao mesmo tempo: do governo francês, do governo brasileiro e de uma instituição alemã! Fiquei rico! Além de continuar estudando muito, mesmo porque era a razão de minhas bolsas, também porque eu tinha juízo, podia ir ao restaurante, aos bares para tomar cerveja, namorar e viajar.

Viajar tornou-se um objetivo complementar à minha formação. Achei que conhecer outros povos, seus costumes, sua cultura, era parte da formação. Uma obrigação, pensava eu, para um estudante interessado em Relações Internacionais. Comecei a viajar. Além das bolsas, as quais eu queria utilizar para melhorar minhas condições de estudo, todos os anos, durante as férias de verão, eu trabalhava dois meses, ganhava um dinheiro a mais, depois viajava um mês. Trabalhei como vendedor de impermeáveis para chuva, no grande magazine de Paris, La Samaritaine. Trabalhei como garçon, em um restaurante de Kaisersberg. Nele aprendi, vendo franceses e alemães comer, a combinar bebida com comida. Trabalhei como garçon em restaurante de uma piscina em Estrasburgo!

Fiz muitas viagens, a lugares diferentes. Além de poder participar de cursos de aperfeiçoamento de francês, em Paris, estive em vários lugares no interior da França.

As viagens mais longas, verdadeiras aventuras, foram poucas mas boas.

Em uma, com colegas estudantes brasileiros, sempre de carro, atravessamos a Alemanha, a Tchecoslováquia, entramos na União Soviética por Usgorod, estivemos em Kiev, na Ucrânia e de lá tomamos o rumo de Moscou, dois mil quilômetros acima. Era engraçado. Não sabíamos uma palavra de russo e, no interior, ninguém falava outra língua. Para pedir comida, por exemplo galinha ou ovo, desenhávamos a coisa no papel e indicávamos para o garçon. Ou então apontávamos o dedo para o prato do vizinho: aquilo! Um dia, como quase não 
achávamos restaurante na estrada, com fome, entramos em uma fazenda à beira da estrada. Serviram-nos muita comida, enchemos a barriga. Quando fomos pagar, mostramos o dinheiro, parecia que os russos viram o demônio: não quiseram saber de dinheiro. Mesmo para encher o tanque de gasolina, nada de dinheiro. Moscou era diferente. Além de um deslumbre. Igrejas, palácios, o Kremlin, restaurantes, muita cerveja, comida boa, gente simpática. De lá, regressamos por Varsóvia, Berlim, para chegar a Estrasburgo.

Em outra viagem, dessa vez com dois estudantes franceses, fomos ao Oriente Próximo. Tínhamos uma "4L", com baixa potência de motor. Para subir montanhas, o motorista dirigia, os outros dois iam atrás, empurrando: uma ajudazinha para o motor! Chegamos a Istambul, outra cidade deslumbrante. Costumes diferentes. Atravessamos o Bósforo, fomos para o outro lado, o interior da Turquia. Lembro de Pamukale e de outras coisas. Passamos pela Síria, até Damasco, depois pela Jordânia. Fomos a Petra, antiga civilização que construía templos dentro das rochas. Estivemos no Líbano, uma joia de beleza, com gente de comportamento mais parecido com costumes europeus. De lá, fomos a Israel. Desse país, onde se podia entrar com o carro, só se saia pelo mar Mediterrâneo. Colocamos o carro em um navio, descemos na ilha de Chipre, fomos à Grécia e voltamos pela costa do Mediterrâneo. Entramos na Itália do Norte, até Veneza. Depois, Estrasburgo. Uma viagem que parecia uma aula.

\section{Na Alemanha. O que mais o impressionou?}

O muro de Berlim, a divisão da Alemanha, metade comunista, metade liberal, com costumes diferentes entre os dois lados. De resto, o que me agradava mesmo, quando estudante em Strasbourg, era a pequena cidade de Kehl, que ficava encostada a Estrasburgo, bastava atravessar a ponte sobre o Reno. Frequentemente eu ia a Kehl, comer e tomar cerveja, sempre de bicicleta e com algum colega estudante.

\section{Com quem viajava?}

Sempre com algum colega. Ou brasileiros ou franceses. 


\section{Você tem outras ideias ou lembranças?}

Muito me lembro de minhas paqueras. Havia vários restaurantes universitários na cidade. Um era judeu, agregado a um colégio residencial, onde moravam estudantes judias que vinham de outros países. Elas eram muito lindas. Enamorei-me de uma judia, do Marrocos, que ficou grávida, e deu à luz a nossa filha. Os pais vieram do Marrocos, a sogra me deu uma bronca, mas aceitaram o casamento, entre uma judia e um católico, de origem italiana. Ficaram meus amigos. Até vieram ao Brasil, anos mais tarde, visitar a filha. Eu mesmo fui ao Marrocos, algumas vezes, e ficava na cidade de praia, Tanger. Assim que trago da França a melhor das lembranças: minha filha.

\section{Como foi a volta ao Brasil?}

Eu tomei o avião, cujo bilhete o governo francês pagou; minha esposa com o neném veio depois, de navio. Ela trazia a mudança, que eram sobretudo roupas e livros. Voltei ao Brasil sem hesitar, mesmo havendo recebido convites para lecionar em outros países, no Oriente Médio e na África.

Queria viver e trabalhar no Brasil, minha terra, meu povo. Cheguei e fui a Passo Fundo visitar meus pais e irmãos.

Um professor da Universidade ficou sabendo, veio à casa de meus pais, menos de um mês depois de minha chegada. Convidou-me para ser professor da Universidade. Fiquei perplexo. $\mathrm{Na}$ França, tornar-se professor de Universidade, era difícil e raro. Mesmo com doutorado. Lembro-me de haver encontrado por acaso, em Paris, anos mais tarde, um colega e amigo meu, doutor por Estrasburgo, e porteiro do hotel onde me hospedara.

Comecei a lecionar na Universidade de Passo Fundo e dei andamento à revalidação dos diplomas. Uma burocracia! Mas, já com emprego, aluguei um apartamento e lá fomos morar: nós três. A vida continuava muito boa.

Seis anos depois, estive em um encontro de professores em Brasília. Como acontecera em Passo Fundo, veio um professor da Universidade de Brasília e falou: o senhor não quer lecionar na Universidade de Brasília? Quero, 
respondi. Achei que era uma promoção profissional. Um mês depois, estávamos morando em Brasília, onde permaneço até hoje.

Minha filosofia de vida não mudou: estudar bastante, trabalhar bastante, fazer amigos, divertir-se bastante, viajar bastante. Tudo deu certo em minha vida. Às vezes, brinco com amigos: tenho inveja de mim mesmo. 